TITLE:

\title{
Photoproduction of Deuterons from Carbon at Several Hundred $\mathrm{MeV}($ Abstract_要旨 )
}

$\operatorname{AUTHOR}(S)$ :

Kihara, Motohiro

CITATION:

Kihara, Motohiro. Photoproduction of Deuterons from Carbon at

Several Hundred MeV. 京都大学, 1965, 理学博士

ISSUE DATE:

1965-06-22

URL:

http://hdl.handle.net/2433/211603

RIGHT: 


\section{[ 21 ]}

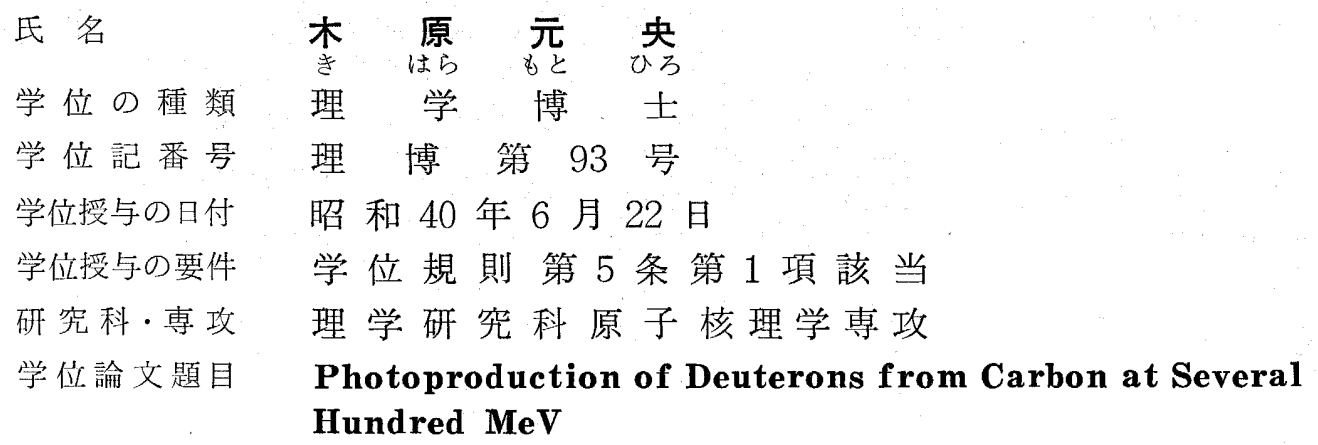

（数百 $\mathrm{MeV}$ に打歪素加らの重陽子光生成）
論文調查委員教辛查安見真次郎教授小林稔教 授 四手井綱彦 教授武藤二郎

\section{論文内容の要旨}

高エネルギー光核反応に执いて，2個の核子の放出される現象を研劣することは，核内の 2 核子の相関 を調べる上で，有力な方法であると考えられる。特に二つの核子が重陽子となって原子核から放出される 過程, 即与 $(\gamma, d)$ 反応は, 一定の終状態のために興味があるが, 高いエネルギー領域（数百 MeV）では 殆んど測定されていない状況である。

主論文は乙の未知の領域の開拓を意図して行なわれたものである。即ち最高エネルギーが $400 \mathrm{MeV}$ から $720 \mathrm{MeV}$ にわたる阻止X線を炭素原子核に照射し，実験室系で $57^{\circ}$ 方向に放出される重陽子及び陽子を 測定した。測定には大型電磁石と 4 個のシンチレーション計数管から成る計数管望遠鏡によって行なわれ た。乙れは電磁石による運動量分析と，第 1 と第 2 のシンチレーション計数管の間を粒子が飛行するに要 する時間間隔の測定とを組み合わせた，一種の質量分析器とあ言える粒子計数装置である。これに用いら れた同時放電回路の時間的分解能は $0.6 \mathrm{~ns}$ に達し，飛行時間測定に用いられた時間一波高变換回路の直 線性は非常に満足す心゙きあのであった。申請者は重陽子を晹子のバックグラウンドから更に明瞭に分離す るために第 3 と第 4 の計数管の間に，その運動量に拉ける重陽子だけを止めるに充分な厚さのアルミニュ ウムの吸收板を置き，第 4 の計数管之他の 3 つの計数管之を反同時放電させるととによって飛行時間スペ クトルにおける重陽子ピークの中への陽子のまざりが無視できる程度に減らすととに成功した。

测定は阻止X線の最高エネルギー 400, $500,530,650,720 \mathrm{MeV}$ の 5 点において夫々 $45 \mathrm{MeV}$ の重陽子, $72 \mathrm{MeV}$ 陽子について実験公系 $57^{\circ}$ 方向の光生成断面積を求め, 更に最高エネルギー $650 \mathrm{MeV}$ と $720 \mathrm{MeV}$ の 2 点に扔いて, 分析電磁石の磁場を変えて重陽子について夫々 $53,63,70 \mathrm{MeV}$; 陽子に対して $92,96,100$ $\mathrm{MeV}$ のエネルギーでそれらの断面積を求めた。これらのデータから，いわゆる photon difference 法に よって $45 \mathrm{MeV}$ 重陽子及び $72 \mathrm{MeV}$ 陽子の生成励起曲線並に光子エネルギー $685 \mathrm{MeV}$ に抬ける重陽子及 び陽子のエネルギー分布曲線を求めた。

申請者は更に進んで上記の実験結果を物理的に解橎するてとを行なっている。即ち光反応機構として独 
立核子対模型を採用し，炭素核内の核子に対しては殼模型の波動函数を用いて $(r, d)$ 反応の微分断面積 の表式を導いた。この光子のエネルギ一範囲は， $\pi$ 中間子一核子系の第一励起状態の高エネルギ一側の裾 より第二励起状態にわたるものであるから，中間子発生を伴うことは言うまでもない。申請者は核内の最 初の核子対として（pn）のみならず（pp）及び（nn）をも考慮に入れて上述の式を導いたのである。

その結果，理論計算值は実験結果をかなりよく再現するととが見出され，乙の事より数百 $\mathrm{MeV}$ 領域に

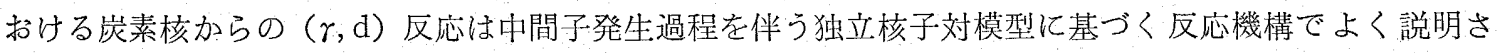
れ得ることを示した。

参考論文その 1 は， 数 $+\mathrm{MeV}$ 陽子による数種類の核についての $(\mathrm{p}, \boldsymbol{a})$ 反応を写真乾板で測定して， 全断面積，角分布，スペクトルのピークのエネルギーの，入射エネルギー並びに標的核の原子番号への依 存性を研究して核反応機構を論じたものである。

参考論文えの 2 は主論文に密接に関連する研究であって, 重陽子からの中性中間子の光発生を第二励起 状態付近で測定し，光子と核子との相互作用の isotopic vector 部分の寄与についての一連の研究の予備 的報告である。

参考論文その 3 は，主論文と同じ研究の速報である。

\section{論文審査の結果の要旨}

光核反応の研究は，実験的にも理論的にも多くの研究者によってなされて来た。これを一言で概括すれ ば，低いエネルギーでは単一粒子励起共鳴が見られるが，20 MeV 付近になると，いわゆる巨大共鳴が起 こって，核は集団励起され，その後の粒子放出は大体統計理論で説明される。とれよりエネルギーが高く なると，光吸収断面積は一旦下降するが，光子エネルギーが中間子閾值以上になると，光中間子発生のた め, 光吸収の断面積は再び増加する。しかし，てれを仔細に検討すれば $25 \mathrm{MeV}$ 以下の比較的低エネルギ 一ですら統計理論と実験との間にかなり大きな不一致が起とっているととがわかる。これらの不一致を説 明する試みには，いわゆる直接相互作用がある。

Levinger は，200 MeV〜300 MeV のエネルギー領域での光核反応におりる放出粒子の高エネルギー部 分を説明するためには，原子核内に括ける二核子間の相関が重要であることを認識して独立核子対模型に 基づく理論的解析を行なった。即ち，（ $\gamma, \mathrm{p}$ ）反応の計算に扔いて彼は擬似重陽子模型を提唱し，乙の反 応の主な特徴は，核内に拈ける擬似重陽子の光崩壊によって理解できることを示した。この Levinger 模 型は， $300 \mathrm{MeV}$ の阻止X線によって原子核からの陽子及び中性子の同時放出を測定した実験によって再

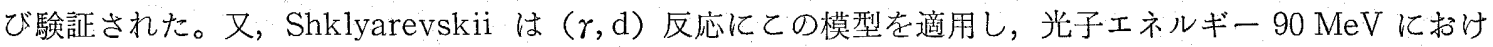
る実験結果とかなりの一致を得た。Kopaleishvili と Jibuti は又この模型を（ $\gamma$, pn） 反応の解析に用い この場合にも核子対の相関が重要な役割を果しているととを結論した。

中間子闘值以上のエネルギーになると，光中間子発生が重要な役割を果して来ることは既述の通りであ， るが，功う高エネルギー領域に招いても2 核子の放出は核構造の研究に有力な手段であると考元られ る。しかしながら，乙の種の研究は極めて少なく，300 MeV 以上では，皆無である。申請者の主論文は 核内の核子相関の問題や 2 核子放出の反応機構について知識を得る目的で，特に 2 核子が重陽子を作って 
放出される場合について $400 \mathrm{MeV} \sim 720 \mathrm{MeV}$ の領域で炭素核について研究した。即ち，申請者は厳密な 粒子識別計数装置を用いて $400 \mathrm{MeV} \sim 720 \mathrm{MeV}$ のエネル゙一笨囲で光重陽子の生成曲線を, $680 \mathrm{MeV}$ 光 子エネルギーに対しては，そのエネルギー分布を湘定することに成功した。これは世界的にみて最初の実

\section{験である。}

申請者は更にインパルス近似及び独立核子対模型に基づいて理論的解析を行ない，微分断面積の表式を 導出した。この際炭素原子核内の（pn）対のみならず（nn）及び（pp）核子対をも考虑に入れている。 実験との一致はかなりよく, 数百 $\mathrm{MeV}$ での光重陽子放出現象は少なくとも近似的には上記の反応機構で 説明出来るととを示した。これは重要な知見であると考える。

申請者は今後の研究課題として重陽子と共に生成される中間子（荷電士, 中性）をむ重陽子と同時に測 定して両者の角相関及び中間子の荷電比の測定を行なえば，原子核構造の研究に有益であろうと指摘して いる。

原子核の構造や核反応機棈を研究するのに素粒子反応を利用する方法は，従来より種々の提案がなされ て来たが，実際には未開拓の分野であると言える。この主論文は，原子核内の核子のふるまいにての方法 を邀用したものとも見られ，ての意味で先駆的な意義があると考える。

以上述べたように，主論文は光核反応の分野に执いて新しい知識を加えたものであって，ての分野の発 展に答与する所が少なくない。

参考論文は，いずれ屯申請者が核物理学及び素粒子物理学の分野に扔いて豊富な知識之優れた研究能力 を持っている事を示している。

よって，本論文は理学博士の学位論文として十分洒值のあることを認める。 